\title{
Article \\ The Link between Corporate Reputation and Financial Performance and Equilibrium within the Airline Industry
}

\author{
Andreas-Daniel Cocis ${ }^{1}$, Larissa Batrancea ${ }^{2, *(D)}$ and Horia Tulai ${ }^{1}$ \\ 1 Faculty of Economics and Business Administration, Babes-Bolyai University, 58-60 Teodor Mihali Street, \\ 400591 Cluj-Napoca, Romania; andreas.cocis@econ.ubbcluj.ro (A.-D.C.); horea.tulai@econ.ubbcluj.ro (H.T.) \\ 2 Faculty of Business, Babes-Bolyai University, 7 Horea Street, 400174 Cluj-Napoca, Romania \\ * Correspondence: larissa.batrancea@ubbcluj.ro
}

check for updates

Citation: Cocis, A.-D.; Batrancea, L.; Tulai, H. The Link between Corporate Reputation and Financial Performance and Equilibrium within the Airline Industry. Mathematics 2021, 9, 2150. https://doi.org /10.3390/math9172150

Academic Editor: David Carfi

Received: 17 August 2021

Accepted: 30 August 2021

Published: 3 September 2021

Publisher's Note: MDPI stays neutral with regard to jurisdictional claims in published maps and institutional affiliations.

Copyright: (c) 2021 by the authors. Licensee MDPI, Basel, Switzerland. This article is an open access article distributed under the terms and conditions of the Creative Commons Attribution (CC BY) license (https:// creativecommons.org/licenses/by/ $4.0 /)$.

\begin{abstract}
This study examines how corporate reputation is perceived by investors through the financial performance and equilibrium of several airline companies. We used a sample of 22 companies. Nineteen are listed in the World Airline Awards 2018 ranking based on client satisfaction, and three companies are included in the Fortune ranking and enjoying the best corporate reputations in the airline industry. The analyzed period was 2016-2018. The purpose of this study was to rank airline companies based on financial indicators by means of the TOPSIS method to see whether the companies included in the Fortune ranking would keep a similar hierarchy. Results indicated that companies maintained a similar order in the TOPSIS ranking after considering financial performance and equilibrium indicators. The overall conclusion was that companies with a good financial performance and equilibrium enjoyed a good corporate reputation from investors' point of view.
\end{abstract}

Keywords: financial performance; financial equilibrium; corporate reputation; TOPSIS method; airline companies

\section{Introduction}

This research focused on different concepts often studied in the literature, namely the perception of corporate reputation through financial performance and equilibrium. These concepts provide information about the company and reveal a positive or a negative result, so that one can create a real picture of company state of health.

In recent years, reputation is a modern concept that has been brought into discussion more and more frequently by the media, researchers, and even stakeholders [1]. Fombrun and Gardberg [2] state that people can be asked to name companies to which they relate and they will voluntarily share an opinion about a particular company. Moreover, if one asks a sample of people about a company and aggregates their answers, one will get a picture of the reputation of that company. Most managers believe that corporate reputation is one of the most sustainable factors in making companies successful [3].

When it comes to the financial performance and equilibrium of companies within the airline industry, which signal their capacity of survival, these concepts have been seldomly taken into account or they have even been ignored [4-6]. Generally, most studies are focused on the operations conducted by these companies. The analysis of financial performance and equilibrium from different industries contributes to making appropriate strategic decisions for each activity [7]. Moreover, the positive evolution of financial performance and equilibrium leads to improved functions and activities for the organizations involved. Within the field of finance, the analysis of financial performance and equilibrium is a very popular topic. For that matter, the factors necessary to improve company financial performance and equilibrium include the following: company size, asset management, operational efficiency, etc. [8,9].

It is obvious that reputation matters. It influences the attitudes and behaviors of not only investors, but also of existing and potential clients, employees, suppliers. It also 
influences regulatory authorities, perceptions of the general public and the media [10]. Hammond and Slocum [11] specify that investors, managers, and recruiters rely on the reputation of organizations for making decisions. A company's reputation sends signals to these stakeholders about their products and business strategies when compared to other companies in similar industries. A favorable reputation has been linked to generating above the average returns for a company.

Financial performance and financial equilibrium are measures expressing the efficient use of assets in generating as much income as possible for a company. The concept of financial performance indicates a company's overall financial health over a period of time. The concept of financial equilibrium captures the degree to which a company manages to covers its short-term and long-term liabilities from its assets. As a general rule, short-term equilibrium is measured via liquidity indicators, while long-term equilibrium is measured via solvency indicators. Analysts and investors use financial performance and equilibrium levels to compare similar companies operating in the same industry [12]. Investors are interested in present, future and expected earnings, as well as in the stability of such revenues. Therefore, we can state that financial performance and equilibrium report the financial health state of a company while assisting various investors and stakeholders to make their investment decisions [13].

Thus, reputation is the result of the perceptions of the company stakeholders. In most cases, reputation is shaped by two key stakeholders: clients and investors. From a client's point of view, a good reputation influences current clients to increase the frequency of purchases for services and products newly launched on the market [14]. Besides the fact that reputation can be shaped by some potential investors, it is mainly formed based on the good results that a company registers, even in difficult times.

In this study, our attention focuses on how corporate reputation is perceived through financial performance and equilibrium from the point of view of investors. According to Davies et al. [15], the AMAC reputation index is believed to be influenced by a company's financial performance. We can therefore infer that, from the investor's point of view, the corporate reputation of a company is perceived as equal to its financial performance and equilibrium. If the company has good financial performance and equilibrium, it also enjoys a good corporate reputation.

We ranked 22 airline companies based on their financial performance and equilibrium (for company details, see the Appendix A) during the period 2016-2018. Eight financial ratios were selected since they are commonly used in the literature when it comes to measuring financial performance and financial equilibrium. By applying the TOPSIS method and aggregating these financial indicators, we succeeded in obtaining an annual score for each company in the sample.

TOPSIS ("Technique for Order of Preference by Similarity to Ideal Solution") is one of the most popular numerical methods regarding multi-criterial decision-making [16]. This technique assumes that the ideal alternative has the best levels for all attributes considered, whereas the least ideal alternative has the worst levels for all attributes considered [17]. TOPSIS is based on the idea that the chosen alternative should have the shortest distance possible from the ideal solution and the longest distance possible from the least ideal solution [18].

Fortune magazine publishes annually a reputable ranking of the most popular American and Non-American companies, based on a sound survey of about 10,000 executives and analysts. The ranking comprises companies from different industries. Our sample numbers three airline companies from this Fortune ranking, which were considered to have the best reputations. We aim to see whether, by aggregating our financial performance and equilibrium indicators via the TOPSIS method, the three companies included in the Fortune ranking will change their position in our hierarchy. 


\section{Literature Review}

A company's reputation is an important component of its value, it is an essential means of measuring financial performance and equilibrium. Reputation is a mechanism that reduces uncertainty for customers, improves marketing efficiency, and increases clients ${ }^{\prime}$ satisfaction [19]. The fact that investors are willing to pay more for company assets is often explained through the concept of corporate reputation. This is an additional intangible company asset for which it is worth paying. Blajer and Kovlowski [20] stated that "a good financial situation determines an increase of a company's reputation when the matter is approached from the investor's point of view". Numerous researchers also believe that reputation is considered to be a valuable intangible asset [3,19,21-23].

The link between financial performance and corporate reputation has often been commented on and scrutinized by many researchers. Juan and Esther [24] claimed that "plenty of authors have shown a positive relation, while others have shown ambiguity or even a negative one". The literature explained this inconsistency by the use of multi-sectoral samples, the multiplication of financial performance measures, and the diversification of the way reputation is built. In addition, it is also reported that uncertainty or ignorance regarding how reputation leads to value creation in a company is often relevant [24].

In their study comprising 230 of the most respected American companies from the perspective of Fortune 2008, Lee and Roh [19] operationalized financial performance through four indicators. Regression analyses revealed that corporate reputation was significantly and positively related to most financial performance indicators. The conclusion of their study was that "corporate reputation seems to appear as a critical dimension of the comparative evaluation of financial performance".

A positive relation between corporate reputation and financial performance has been confirmed by numerous empirical studies, including the one by Ayturk et al. [25]. This study examined the link corporate reputation-financial performance in Turkey. Results showed that although corporate reputation did not significantly determine financial performance measured by return on assets and return on equity, Turkish companies managed to improve corporate reputation.

Many studies have focused on the effect of developing social responsibility, corporate reputation, and financial performance. In this sense, Arshad et al. [26] reported that social responsibility activities carried out by several companies and disclosed in their annual financial reports were directly related to corporate reputation, as well as to financial performance. Hence, authors asserted that there might be a reciprocal link between corporate reputation and financial performance.

On the one hand, shareholders, managers and brokers are likely to focus more on financial performance and equilibrium than reputation. On the other hand, in case of the general public, the financial performance and equilibrium of a company will not be taken into account when establishing the company reputation [27]. If one is a potential investor, one will automatically be interested in and calculate certain performance and equilibrium indicators to better assess the company state, either positively or negatively. From a position of potential investor, after determining the financial performance and equilibrium indicators, one can interpret reputations for each company.

Flanagan et al. [28] found that measuring company reputation by means of Fortune rankings was strongly influenced by past financial performance. They also were interested in analyzing more recent data related to company reputation determined by Fortune to identify changes over time. The main finding was that, in this case, the relationship was less strong than reported by other studies in the literature. As previously mentioned, this Fortune ranking is published annually and is survey-based. Companies are assessed on the following eight attributes: quality of management, quality of products and services, innovation, long-term investment value, financial stability, ability to hire competent staff, environmental responsibilities, and wise use of assets. Fryxell and Wang [29] criticized the fact that in the calculation of the Fortune index, out of the eight variables, four variables capture financial performance. 


\section{Financial Indicators}

Evaluating financial performance and equilibrium based on past financial statements plays an extremely important role in maximizing the market value of the company, in ensuring a financial balance, but also helps with improving the sector where companies activate. Financial indicators provide information about the health state of the company, its risks and profit.

On stock markets, financial reports are usually grouped into certain categories, because expert accountants assume that financial reports from a category are partially similar [4]. Thus, we selected some of the most popular financial indicators from five categories: profitability, growth, financial strength, liquidity, and turnover.

We selected the following financial indicators: return on assets (ROA); return on equity (ROE); earnings per share (EPS); financial leverage (DER); debt to asset ratio (DAR); quick ratio $(\mathrm{QR})$; current ratio $(\mathrm{CR})$; and accounts receivable turnover (ART). With respect to the profitability indicators, we will use the pre-tax versions of the indicators (i.e., pre-tax ROA; pre-tax ROE). Given that companies are from different countries and different tax systems, the level of taxation is different $[30,31]$. We did not want to have taxation influencing the empirical results. Thus, we decided to use "income before taxes" instead of "net income" when determining ROA and ROE. The formulas for all indicators are presented in Table 1.

Table 1. Indicators chosen.

\begin{tabular}{ccc}
\hline Category & Indicator & Formula \\
\hline Profitability & $\begin{array}{c}\text { Pre-tax ROA } \\
\text { Pre-tax ROE }\end{array}$ & $\begin{array}{c}\text { Income before taxes/Total assets } \\
\text { Income before taxes/Shareholders' equity }\end{array}$ \\
\hline Growth & Earnings per share (EPS) & Net annual income/Number of shares \\
\hline $\begin{array}{c}\text { Financial } \\
\text { strength }\end{array}$ & $\begin{array}{c}\text { Financial leverage (DER) } \\
\text { Debt to asset ratio (DAR) }\end{array}$ & $\begin{array}{c}\text { Total debts/Shareholders' equity } \\
\text { Total debts/Total assets }\end{array}$ \\
\hline Liquidity & Quick ratio (QR) & Current ratio (CR) \\
\hline Turnover & Accounts receivable turnover (ART) & Net credit sales/Average accounts receivable \\
\hline
\end{tabular}

1. Return on assets (ROA) is used in numerous studies by most researchers $[25,32,33]$. The ratio measures the performance level of company assets. In our case, pre-tax ROA is determined as the ratio of income before taxes to total assets.

2. Return on equity (ROE) is also a very commonly used indicator in determining the financial performance of companies [25,32,33]. The ratio measures the efficiency of the use of own company capital (i.e., equity). In our case, pre-tax ROE is determined as the ratio of income before taxes to shareholders' equity.

3. Earnings per share (EPS) is an indicator capturing the return on capital growth. It is determined as the ratio of the company net result for the year to the number of shares. The higher a company's ratio, the more profitable the company is.

4. Financial leverage (DER) expresses the degree to which company indebtedness level impacts on its own capital. In other words, DER assesses the company's ability to meet its financial obligations. The indicator is determined as the ratio of total debt to shareholders' equity.

5. Quick ratio (QR) measures the ability of the company to use its highly liquid assets in order to respond immediately to short-term financial debts. The indicator is often called the "acid test". QR is determined by dividing current assets after subtracting the inventory and current liabilities [4,34].

6. Current ratio (CR) is the liquidity indicator that measures a company's ability to pay its short-term obligations. This indicator is determined by dividing current assets and current liabilities [4,34].

7. Accounts receivable turnover (ART) captures the state of company health when talking about its success in collecting receivables from clients. The indicator is determined as the ratio of net credit sales to average accounts receivable [35]. 
8. Debt to asset ratio (DAR) defines the total value of company debt in reference to its assets. It shows the capacity of the company to finance its assets from external funds. The indicator is often used by analysts to compare companies from the same industry. DAR is determined as the ratio of total debts to total assets [36].

\section{Methodology}

Our main idea is to build a ranking of the 22 airline companies based on their financial performance and equilibrium. The ranking will be obtained using the TOPSIS method, which is based on aggregating several criteria. We chose a number of eight financial indicators, each measuring an aspect related to the financial performance and equilibrium of the respective companies. The selection of companies was based on the ranking published by World Airline Awards, which is compiled from global surveys regarding clients' satisfaction with airline companies. In this sense, the first 19 companies with publicly available data out of the 100 listed in 2018 were taken into account. In addition, three companies from the Fortune ranking were also considered (see Table 2).

Table 2. The Fortune airline companies included in the ranking for their best company reputations.

\begin{tabular}{|c|c|c|c|c|c|}
\hline \multicolumn{2}{|c|}{2018} & \multicolumn{2}{|l|}{2017} & \multicolumn{2}{|c|}{2016} \\
\hline Company & $\begin{array}{c}\text { Fortune } \\
\text { Rank }\end{array}$ & Company & $\begin{array}{c}\text { Fortune } \\
\text { Rank }\end{array}$ & Company & $\begin{array}{c}\text { Fortune } \\
\text { Rank }\end{array}$ \\
\hline $\begin{array}{c}\text { Southwest } \\
\text { Airlines }\end{array}$ & 8 & $\begin{array}{c}\text { Southwest } \\
\text { Airlines }\end{array}$ & 8 & $\begin{array}{c}\text { Southwest } \\
\text { Airlines }\end{array}$ & 7 \\
\hline Delta Air Lines & 31 & Delta Air Lines & 31 & Delta Air Lines & 30 \\
\hline $\begin{array}{c}\text { Singapore } \\
\text { Airlines }\end{array}$ & 32 & $\begin{array}{c}\text { Singapore } \\
\text { Airlines }\end{array}$ & 33 & $\begin{array}{c}\text { Singapore } \\
\text { Airlines }\end{array}$ & - \\
\hline
\end{tabular}

9 December 2020).

Only these three companies from the airline industry are included in the Fortune ranking as having the best reputations. As previously mentioned, the ranking is compiled for the best reputations of 500 companies from different industries. Hence, Southwest Airlines enjoyed the 8th place both in 2018 and 2017. Delta Air Lines had the best reputation in 2016, enjoying the 30th place. Singapore Airlines was the third airline company included in this ranking beginning with 2017.

After having the Fortune ranking of these airline companies included in the sample, we are interested to see whether their hierarchy remains the same according to our ranking. The financial information for each of the 22 companies were retrieved from their financial statements (i.e., balance sheet, income statement) and the Thomson Reuters database.

As a multi-criteria analysis method, we used the "Technique for Order of Preference by Similarity to Ideal Solution" (TOPSIS) developed by Hwang and Yoon [37]. The basic mechanism of the method is to define the ideal and the least ideal solutions. The method is based on the concept of distance, which chooses the alternative that is closest to the ideal solution. In other words, the ideal solution is the one that maximizes the benefit criteria and minimizes the cost criteria, while the least ideal solution is the one that maximizes the cost criteria and minimizes the benefit criteria $[4,38]$. In our research study, the ideal solution consists in the best values achieved for each criterion, while the least ideal solution consists in the worst values achieved for each criterion.

First, one has to compile the matrix of original data. Thus, TOPSIS turns the matrix of original data into a normalized matrix. The method has six steps to be followed until the final score is determined.

The method evaluates the following decision matrix, which contains $m$ alternatives associated with $n$ attributes (or criteria): 
where:

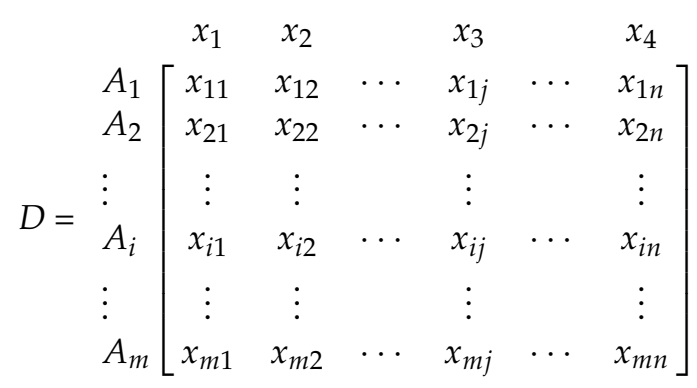

$A_{i}=$ the $i^{\text {th }}$ alternative considered;

$x_{i j}=$ the numerical outcome of the $i^{\text {th }}$ alternative with respect to the $j^{\text {th }}$ criterion.

Step 1. Normalization of alternative values. There are many choices for normalizing alternative values. We will use the vector normalization, which is based on the ratio of the original value $\left(x_{i j}\right)$ to the square root of the sum of the original indicator values. This procedure is usually employed by TOPSIS [34]. The formula is as follows:

$$
r_{i j}=\frac{x_{i j}}{\sqrt{\sum_{l=1}^{m} x_{l j}^{2}}},
$$

where:

$i$ is the $i^{\text {th }}$ airline company; $j$ the $j^{\text {th }}$ evaluation indicator;

$r_{i j}$ the indicator value after the vector normalization for the $i^{\text {th }}$ airline company and $j^{\text {th }}$ evaluation indicator;

$x_{i j}$ is the original value of indicators for the $i^{\text {th }}$ airline company and $j^{\text {th }}$ evaluation indicator; $m$ the number of airline companies.

Step 2. Determination of the weighted normalized matrix, with coefficients depending on the importance of criteria.

$$
V=\left[v_{i j}\right], v_{i j}=w_{j} * r_{i j}
$$

where:

$w=\left(w_{1}, w_{2}, \ldots, w_{j}, \ldots, w_{n}\right), \sum_{j=1}^{n} w_{j}=1$

The weighted normalized decision matrix $V$ is equal to:

$$
V=\left[\begin{array}{cccccc}
v_{11} & v_{12} & \cdots & v_{1 j} & \cdots & v_{1 n} \\
\vdots & \vdots & & \vdots & & \vdots \\
v_{i 1} & v_{i 2} & \cdots & v_{i j} & \cdots & v_{i n} \\
\vdots & \vdots & & \vdots & & \vdots \\
v_{m 1} & v_{m 2} & \cdots & v_{m j} & \cdots & v_{m n}
\end{array}\right]=\left[\begin{array}{cccccc}
w_{1} r_{11} & w_{2} r_{12} & \cdots & w_{j} r_{i j} & \cdots & w_{n} r_{1 n} \\
\vdots & \vdots & & \vdots & & \vdots \\
w_{1} r_{i 1} & w_{2} r_{i 2} & \cdots & w_{j} r_{i j} & \cdots & w_{n} r_{i n} \\
\vdots & \vdots & & \vdots & & \vdots \\
w_{1} r_{m 1} & w_{2} r_{m 2} & \cdots & w_{j} r_{m j} & \cdots & w_{n} r_{m n}
\end{array}\right]
$$

Step 3. Defining the ideal positive solution vectors $V^{+}$and the ideal negative solution vectors $V^{-}$, as follows:

$$
\begin{aligned}
& \boldsymbol{V}^{+}=\left(\boldsymbol{v}_{\mathbf{1}^{+}}\right),\left(\boldsymbol{v}_{2^{+}}\right), \ldots,\left(\boldsymbol{v}_{n^{+}}\right), \\
& \boldsymbol{V}^{-}=\left(\boldsymbol{v}_{1^{-}}\right),\left(\boldsymbol{v}_{2^{-}}\right), \ldots,\left(\boldsymbol{v}_{n^{-}}\right),
\end{aligned}
$$

where $v_{j}$ :

$$
\begin{array}{r}
v_{j^{+}} \max \left(v_{i j}\right) \text {, when } C_{j} \text { is the criterion expressing the maximum; } \\
\min \left(v_{i j}\right), \text { when } C_{j} \text { is the criterion expressing the minimum. } \\
v_{j^{-}} \max \left(v_{i j}\right), \text { when } C_{j} \text { is the criterion expressing the maximum; } \\
\min \left(v_{i j}\right), \text { when } C_{j} \text { is the criterion expressing the minimum. }
\end{array}
$$


Step 4. Calculation of the Euclidian distance between a current variant $V_{i}$ and the solution variant $V^{+}$and $V^{-}$, respectively:

$$
\begin{aligned}
& S_{i^{+}}=\sqrt{\sum_{j=1}^{k}\left(v_{i j}-v_{j^{+}}\right)^{2}} \\
& S_{i^{-}}=\sqrt{\sum_{j=1}^{k}\left(v_{i j}-v_{j^{-}}\right)^{2}}
\end{aligned}
$$

where $i=1,2, \ldots m$.

Step 5. Calculation of the relative closeness to the ideal solution $\left(C^{*}\right)$ :

$$
C_{i}^{*}=\frac{\sqrt{\sum_{j=1}^{k}\left(v_{i j}-v_{j^{-}}\right)^{2}}}{\sqrt{\sum_{j=1}^{k}\left(v_{i j}-v_{j^{+}}\right)^{2}}+\sqrt{\sum_{j=1}^{k}\left(v_{i j}-v_{j^{-}}\right)^{2}}}=\frac{S_{i^{-}}}{S_{i^{+}}+S_{i^{-}}},
$$

where $0<C_{i}^{*}<1$.

Step 6. Drafting of the ranking of companies, determined in a decreasing order of the final score.

\section{Data Analysis}

We chose eight financial indicators as criteria for further selection of the companies, which are determined using financial data from the balance sheet, income statement, and different financial information from the Thomson Reuters database. Thus, we obtained a $22 \times 8$ matrix for every year in the period 2016-2018 corresponding to the 22 companies and the 8 financial indicators, which were: return on assets, return on equity, earnings per share, financial leverage, debt to assets ratio, quick ratio, current ratio, and accounts receivable turnover.

Next, for the purpose of this study, we gave equal weight (12.5\%) to each criterion because the indicators have the same significance.

Finally, by means of the TOPSIS method, we obtained a ranking of these companies according to the financial performance and equilibrium indicators established as criteria. The financial indicators for the year 2018 are presented in Table 3, which assisted us in preparing the decision matrix.

After compiling the matrix with the original values of the indicators for each airline company, we normalized them by using the formula from the first stage of the TOPSIS method. Table 4 displays the normalized results.

The weighted normalized matrix is determined by multiplying each value of the indicator by $12.5 \%$ (Table 5 ).

Next, we calculated the Euclidian distance, which was determined by using the maximum and minimum values for each criterion in the weighted normalized matrix table.

$S^{+}=(0.12658 ; 0.09396 ; 0.06530 ; 0.12028 ; 0.10331 ; 0.13745 ; 0.09224 ; 0.07444 ; 0.18101 ;$ $0.06187 ; 0.12215 ; 0.09353 ; 0.10771 ; 0.08695 ; 0.11995 ; 0.13135 ; 0.10635 ; 0.14698 ; 0.10315$; $0.11330 ; 0.05168 ; 0.07009)$.

$S^{-}=(0.10132 ; 0.12257 ; 0.13686 ; 0.09478 ; 0.11050 ; 0.07983 ; 0.13654 ; 0.14806 ; 0.02443 ;$ $0.15075 ; 0.09624 ; 0.12368 ; 0.11096 ; 0.13816 ; 0.09866 ; 0.08337 ; 0.10884 ; 0.06082 ; 0.10654$; $0.09642 ; 0.16790 ; 0.16142)$.

Finally, in order to determine the closeness to the ideal solution for these airline companies, we applied the formula from step 5 of the TOPSIS method. Following this step, the process of assessing the financial performance and equilibrium for the 22 airline companies was completed. Rankings were determined in a descending order, depending on the values of our TOPSIS index (Table 6). 
Table 3. Original data matrix (for 2018).

\begin{tabular}{|c|c|c|c|c|c|c|c|c|}
\hline & Pre-Tax ROA & Pre-Tax ROE & EPS & DER & QR & ART & $\mathrm{CR}$ & DAR \\
\hline Qatar Airways & $-0.2 \%$ & $-0.30 \%$ & -0.06 & $31.90 \%$ & 0.68 & 0.41 & 0.72 & $19.90 \%$ \\
\hline Singapore Airlines & $6.20 \%$ & $11.70 \%$ & 3.18 & $23.60 \%$ & 0.73 & 11.76 & 0.76 & $12.10 \%$ \\
\hline ANA All Nippon Airways & $8.10 \%$ & $20.40 \%$ & 14.84 & $79.80 \%$ & 1.02 & 12 & 1.12 & $31.20 \%$ \\
\hline Cathay Pacific Airways & $0.80 \%$ & $2.40 \%$ & 0.3 & $115.60 \%$ & 0.57 & 9.53 & 0.61 & $38.80 \%$ \\
\hline EVA Air & $3.90 \%$ & $13.60 \%$ & 0.17 & $139.70 \%$ & 1.17 & 10.31 & 0.92 & $40.60 \%$ \\
\hline Hainan Airlines & $-2.5 \%$ & $-7.0 \%$ & -0.13 & $157.70 \%$ & 0.44 & 7.71 & 0.44 & $53.00 \%$ \\
\hline Qantas Airways & $7.50 \%$ & $35.70 \%$ & 1.63 & $120.10 \%$ & 0.43 & 21.09 & 0.48 & $25.50 \%$ \\
\hline Lufthansa & $7.50 \%$ & $29.80 \%$ & 21.28 & $70.20 \%$ & 0.6 & 6.38 & 0.66 & $17.60 \%$ \\
\hline Thai Airways & $-4.2 \%$ & $-44.2 \%$ & -0.65 & $739.50 \%$ & 0.5 & 12.96 & 0.56 & $56.30 \%$ \\
\hline Japan Airlines & $9.10 \%$ & $15.50 \%$ & 13.61 & $11.50 \%$ & 1.66 & 9.44 & 1.71 & $6.80 \%$ \\
\hline China Southern Airlines & $1.90 \%$ & $6.40 \%$ & 0.17 & $161.80 \%$ & 0.27 & 15.83 & 0.29 & $51.30 \%$ \\
\hline Air New Zealand & $6.80 \%$ & $24.40 \%$ & 0.95 & $125.60 \%$ & 0.81 & 13.94 & 0.84 & $34.90 \%$ \\
\hline Bangkok Airways & $0.60 \%$ & $1.20 \%$ & 0.01 & $57.20 \%$ & 1.31 & 14.1 & 1.37 & $28.40 \%$ \\
\hline AirAsia & $7.20 \%$ & $22.30 \%$ & 0.59 & $19.50 \%$ & 1.27 & 11 & 1.29 & $6.50 \%$ \\
\hline Air France & $2.10 \%$ & $29.10 \%$ & 4.05 & $591.60 \%$ & 0.58 & 10.01 & 0.63 & $37.20 \%$ \\
\hline Virgin Australia & $-3.2 \%$ & $-15.1 \%$ & -0.05 & $234.50 \%$ & 0.77 & 26.28 & 0.78 & $41.50 \%$ \\
\hline Turk Hava Yollari & $4.90 \%$ & $16.90 \%$ & 0.46 & $178.40 \%$ & 0.83 & 9.06 & 0.87 & $51.20 \%$ \\
\hline Asiana Airlines Inc & $-3.0 \%$ & $-20.9 \%$ & -0.74 & $314.70 \%$ & 0.37 & 13.92 & 0.45 & $42.00 \%$ \\
\hline Finnair Plc & $3.20 \%$ & $13.50 \%$ & 0.7 & $193.20 \%$ & 1.05 & 12.85 & 1.07 & $45.00 \%$ \\
\hline China Airlines & $1.40 \%$ & $5.20 \%$ & 0.01 & $183.10 \%$ & 0.72 & 16.81 & 0.87 & $47.80 \%$ \\
\hline Southwest Airlines & $12.30 \%$ & $32.50 \%$ & 16.93 & $34.80 \%$ & 0.58 & 35.72 & 0.64 & $13.10 \%$ \\
\hline Delta Air Lines & $9.00 \%$ & $39.30 \%$ & 22.35 & $71.40 \%$ & 0.28 & 18.95 & 0.34 & $16.20 \%$ \\
\hline
\end{tabular}

Table 4. Normalized data matrix (for 2018).

\begin{tabular}{|c|c|c|c|c|c|c|c|c|}
\hline & Pre-Tax ROA & Pre-Tax ROE & EPS & DER & QR & ART & CR & DAR \\
\hline Qatar Airways & -0.0055 & -0.0029 & -0.0015 & 0.028 & 0.1737 & 0.0057 & 0.1785 & 0.118 \\
\hline Singapore Airlines & 0.2281 & 0.1121 & 0.0777 & 0.0208 & 0.1865 & 0.1631 & 0.187 & 0.0715 \\
\hline ANA All Nippon Airways & 0.298 & 0.1958 & 0.3624 & 0.0702 & 0.2606 & 0.1665 & 0.2759 & 0.1843 \\
\hline Cathay Pacific Airways & 0.0288 & 0.0227 & 0.0073 & 0.1017 & 0.1456 & 0.1322 & 0.1514 & 0.2297 \\
\hline EVA Air & 0.1442 & 0.1306 & 0.0042 & 0.123 & 0.2989 & 0.143 & 0.2269 & 0.2403 \\
\hline Hainan Airlines & -0.0917 & -0.0671 & -0.0032 & 0.1388 & 0.1124 & 0.107 & 0.1084 & 0.3133 \\
\hline Qantas Airways & 0.2758 & 0.3419 & 0.0398 & 0.1057 & 0.1099 & 0.2926 & 0.1183 & 0.1506 \\
\hline Lufthansa & 0.2784 & 0.2856 & 0.5197 & 0.0618 & 0.1533 & 0.0885 & 0.1624 & 0.1041 \\
\hline Thai Airways & -0.1560 & -0.4239 & -0.0159 & 0.6509 & 0.1277 & 0.1798 & 0.1377 & 0.333 \\
\hline Japan Airlines & 0.3353 & 0.1484 & 0.3324 & 0.0101 & 0.4241 & 0.131 & 0.4238 & 0.0401 \\
\hline China Southern Airlines & 0.0713 & 0.0612 & 0.0042 & 0.1424 & 0.069 & 0.2196 & 0.0711 & 0.3037 \\
\hline Air New Zealand & 0.2495 & 0.2334 & 0.0232 & 0.1106 & 0.2069 & 0.1934 & 0.2065 & 0.2062 \\
\hline Bangkok Airways & 0.0218 & 0.0116 & 0.0002 & 0.0503 & 0.3347 & 0.1956 & 0.3387 & 0.1677 \\
\hline AirAsia & 0.2647 & 0.214 & 0.0144 & 0.0171 & 0.3244 & 0.1526 & 0.3188 & 0.0385 \\
\hline Air France & 0.078 & 0.2787 & 0.0989 & 0.5207 & 0.1482 & 0.1389 & 0.1557 & 0.2202 \\
\hline Virgin Australia & -0.1187 & -0.1446 & -0.0012 & 0.2064 & 0.1967 & 0.3646 & 0.1928 & 0.2455 \\
\hline Turk Hava Yollari & 0.1811 & 0.1619 & 0.0112 & 0.1571 & 0.212 & 0.1257 & 0.215 & 0.3027 \\
\hline Asiana Airlines & -0.1094 & -0.1999 & -0.0181 & 0.277 & 0.0945 & 0.1931 & 0.1112 & 0.2484 \\
\hline Finnair & 0.1198 & 0.1298 & 0.0171 & 0.17 & 0.2682 & 0.1783 & 0.2644 & 0.2661 \\
\hline China Airlines & 0.0499 & 0.0495 & 0.0002 & 0.1612 & 0.1839 & 0.2332 & 0.215 & 0.2826 \\
\hline Southwest Airlines & 0.4555 & 0.3111 & 0.4135 & 0.0306 & 0.1482 & 0.4956 & 0.1572 & 0.0772 \\
\hline Delta Air Lines & 0.3342 & 0.3766 & 0.5458 & 0.0628 & 0.0715 & 0.2629 & 0.0843 & 0.0959 \\
\hline
\end{tabular}


Table 5. Weighted normalized data matrix (for 2018).

\begin{tabular}{|c|c|c|c|c|c|c|c|c|}
\hline & Pre-Tax ROA & Pre-Tax ROE & EPS & DER & QR & ART & CR & DAR \\
\hline Qatar Airways & -0.0007 & -0.0004 & -0.0002 & 0.0035 & 0.0217 & 0.0007 & 0.0223 & 0.0147 \\
\hline Singapore Airlines & 0.0285 & 0.0140 & 0.0097 & 0.0026 & 0.0233 & 0.0204 & 0.0234 & 0.0089 \\
\hline ANA All Nippon Airways & 0.0372 & 0.0245 & 0.0453 & 0.0088 & 0.0326 & 0.0208 & 0.0345 & 0.0230 \\
\hline Cathay Pacific Airways & 0.0036 & 0.0028 & 0.0009 & 0.0127 & 0.0182 & 0.0165 & 0.0189 & 0.0287 \\
\hline EVA Air & 0.0180 & 0.0163 & 0.0005 & 0.0154 & 0.0374 & 0.0179 & 0.0284 & 0.0300 \\
\hline Hainan Airlines & -0.0115 & -0.0084 & -0.0004 & 0.0174 & 0.0141 & 0.0134 & 0.0135 & 0.0392 \\
\hline Qantas Airways & 0.0345 & 0.0427 & 0.0050 & 0.0132 & 0.0137 & 0.0366 & 0.0148 & 0.0188 \\
\hline Lufthansa & 0.0348 & 0.0357 & 0.0650 & 0.0077 & 0.0192 & 0.0111 & 0.0203 & 0.0130 \\
\hline Thai Airways & -0.0195 & -0.0530 & -0.0020 & 0.0814 & 0.0160 & 0.0225 & 0.0172 & 0.0416 \\
\hline Japan Airlines & 0.0419 & 0.0186 & 0.0415 & 0.0013 & 0.0530 & 0.0164 & 0.0530 & 0.0050 \\
\hline China Southern Airlines & 0.0089 & 0.0077 & 0.0005 & 0.0178 & 0.0086 & 0.0275 & 0.0089 & 0.0380 \\
\hline Air New Zealand & 0.0312 & 0.0292 & 0.0029 & 0.0138 & 0.0259 & 0.0242 & 0.0258 & 0.0258 \\
\hline Bangkok Airways & 0.0027 & 0.0014 & 0.0000 & 0.0063 & 0.0418 & 0.0245 & 0.0423 & 0.0210 \\
\hline AirAsia & 0.0331 & 0.0267 & 0.0018 & 0.0021 & 0.0406 & 0.0191 & 0.0399 & 0.0048 \\
\hline Air France & 0.0098 & 0.0348 & 0.0124 & 0.0651 & 0.0185 & 0.0174 & 0.0195 & 0.0275 \\
\hline Virgin Australia & -0.0148 & -0.0181 & -0.0002 & 0.0258 & 0.0246 & 0.0456 & 0.0241 & 0.0307 \\
\hline Turk Hava Yollari & 0.0226 & 0.0202 & 0.0014 & 0.0196 & 0.0265 & 0.0157 & 0.0269 & 0.0378 \\
\hline Asiana Airlines Inc & -0.0137 & -0.0250 & -0.0023 & 0.0346 & 0.0118 & 0.0241 & 0.0139 & 0.0311 \\
\hline Finnair Plc & 0.0150 & 0.0162 & 0.0021 & 0.0213 & 0.0335 & 0.0223 & 0.0331 & 0.0333 \\
\hline China Airlines & 0.0062 & 0.0062 & 0.0000 & 0.0201 & 0.0230 & 0.0292 & 0.0269 & 0.0353 \\
\hline Southwest Airlines & 0.0569 & 0.0389 & 0.0517 & 0.0038 & 0.0185 & 0.0619 & 0.0196 & 0.0096 \\
\hline Delta Air Lines & 0.0418 & 0.0471 & 0.0682 & 0.0079 & 0.0089 & 0.0329 & 0.0105 & 0.0120 \\
\hline
\end{tabular}

Table 6. Scores and rankings by company.

\begin{tabular}{ccccccc}
\hline & \multicolumn{2}{c}{$\mathbf{2 0 1 8}$} & \multicolumn{2}{c}{$\mathbf{2 0 1 7}$} & \multicolumn{2}{c}{$\mathbf{2 0 1 6}$} \\
\cline { 2 - 6 } & $\boldsymbol{C}_{\boldsymbol{i}}^{*}$ & Rank & $\boldsymbol{C}_{\boldsymbol{i}}^{*}$ & Rank & $\boldsymbol{C}_{\boldsymbol{i}}^{*}$ & Rank \\
\hline Qatar Airways & 0.4446 & 16 & 0.4633 & 11 & 0.4263 & 13 \\
Singapore Airlines & 0.5661 & 9 & 0.4548 & 12 & 0.4551 & 10 \\
ANA All Nippon Airways & 0.6770 & 4 & 0.5680 & 5 & 0.4856 & 8 \\
Cathay Pacific Airways & 0.4407 & 17 & 0.3871 & 17 & 0.3370 & 18 \\
EVA Air & 0.5168 & 10 & 0.4361 & 13 & 0.3954 & 15 \\
Hainan Airlines & 0.3674 & 20 & 0.4023 & 16 & 0.4102 & 14 \\
Qantas Airways & 0.5968 & 7 & 0.5245 & 6 & 0.4987 & 6 \\
Lufthansa & 0.6654 & 5 & 0.6824 & 4 & 0.5629 & 4 \\
Thai Airways & 0.1189 & 22 & 0.1934 & 22 & 0.2531 & 21 \\
Japan Airlines & 0.7090 & 2 & 0.6962 & 2 & 0.6386 & 3 \\
China Southern Airlines & 0.4407 & 18 & 0.4035 & 15 & 0.3827 & 16 \\
Air New Zealand & 0.5694 & 8 & 0.4979 & 8 & 0.4948 & 7 \\
Bangkok Airways & 0.5074 & 12 & 0.4776 & 10 & 0.4845 & 9 \\
AirAsia & 0.6138 & 6 & 0.5147 & 7 & 0.4499 & 12 \\
Air France & 0.4513 & 15 & 0.2807 & 21 & 0.5194 & 5 \\
Virgin Australia & 0.3883 & 19 & 0.3070 & 20 & 0.2241 & 22 \\
Turk Hava Yollari & 0.5058 & 13 & 0.3607 & 19 & 0.3157 & 19 \\
Asiana Airlines & 0.2927 & 21 & 0.4110 & 14 & 0.2799 & 20 \\
Finnair Plc & 0.5081 & 11 & 0.4914 & 9 & 0.4532 & 11 \\
China Airlines & 0.4598 & 14 & 0.3688 & 18 & 0.3445 & 17 \\
Southwest Airlines & 0.7646 & 1 & 0.7375 & 1 & 0.6780 & 1 \\
Delta Air Lines & 0.6972 & 3 & 0.6909 & 3 & 0.6634 & 2 \\
\hline
\end{tabular}

If the value of the TOPSIS index is higher, it means that it is closer to the ideal solution and further away from the least ideal solution. Hence, this index represents an alternative between the ideal option and the least ideal option.

As displayed in Table 6, Southwest Airlines ranked first across the entire period of analysis, the company was the best in terms of financial performance and equilibrium since it registered the maximum scores. The companies Japan Airlines and Delta Air Lines occupied top places in this ranking, being the second and the third best companies. 
As can be seen in Table 7, the companies included in the Fortune ranking (i.e., Southwest, Delta Air and Singapore) maintained a similar order also in the TOPSIS ranking during the entire period analyzed. Therefore, we can infer how important financial performance and financial equilibrium are in determining reputation.

Table 7. Final results.

\begin{tabular}{cccccccccc}
\hline & $\mathbf{2 0 1 8}$ & \multicolumn{1}{c}{$\mathbf{2 0 1 7}$} & & & 2016 \\
\hline Company & $\begin{array}{c}\text { Fortune } \\
\text { Rank }\end{array}$ & $\begin{array}{c}\text { TOPSIS } \\
\text { Rank }\end{array}$ & Company & $\begin{array}{c}\text { Fortune } \\
\text { Rank }\end{array}$ & $\begin{array}{c}\text { TOPSIS } \\
\text { Rank }\end{array}$ & $\begin{array}{c}\text { Company } \\
\text { Fortune } \\
\text { Rank }\end{array}$ & $\begin{array}{c}\text { TOPSIS } \\
\text { Rank }\end{array}$ \\
\hline Southwest & 8 & 1 & Southwest & 8 & 1 & Southwest & 7 & 1 \\
\hline Delta Air & 31 & 3 & Delta Air & 31 & 3 & Delta Air & 30 & 2 \\
\hline Singapore & 32 & 9 & Singapore & 33 & 12 & Singapore & - & 10 \\
\hline
\end{tabular}

It is worth mentioning that Southwest Airlines and Delta Air Lines were not included among the top 40 companies in the 2018 World Airline Awards ranking related to client satisfaction, even if they ranked first among airline companies in the Fortune ranking. This result highlights a discrepancy between the two existing market players, namely clients and investors. In general, interests are pursued according to the needs of each stakeholder: for a client, comfort and responsibility are valuable; for an investor, profitability and returns are important.

\section{Conclusions}

Corporate reputation is linked to financial performance and equilibrium, as Lee and Roh [19] specified. Therefore, companies with a high (positive) reputation level also register good financial performance and equilibrium levels. Investors who follow both the financial performance and equilibrium of a company and its corporate reputation provided by the Fortune hierarchy will be able to make investment decisions only when companies register positive results.

As Roberts and Dowling [39] pointed out, investors do not have access to all data about a company, so their decisions are largely based on previous levels of financial indicators as a means of determining a company's overall reputation. Following this observation, we imply that the reputation of a company identifies with its financial performance and equilibrium from an investor's point of view. In other words, good financial performance and equilibrium are mirrored by a good corporate reputation, while poor financial performance and equilibrium indicate a poor corporate reputation.

When it comes to making decisions based on multiple criteria, one of the most popular approaches recommended in the literature is the TOPSIS method. The present study contributes to the literature by applying the TOPSIS method in order to rank 22 airline companies according to their financial performance and financial equilibrium levels for the period 2016-2018. Eight relevant indicators capturing performance and equilibrium were selected and aggregated via the TOPSIS algorithm to produce an annual company score and equivalent ranking. Empirical results showed that the proposed TOPSIS annual ranking of three airline companies was similar to their hierarchy as listed by the Fortune ranking. Our conclusion was that companies registering solid financial performance and financial equilibrium levels also enjoyed solid corporate reputations in the eyes of global investors.

The study has certain limitations. First, the company sample included 22 major players in the airline industry around the world. Future studies might consider expanding the sample by including several other companies from each continent and especially those listed in the annual Fortune ranking. Second, the analyzed time frame was limited to 2016-2018. Future investigations might consider a longer period of time covering the current pandemic since it had a big impact on the airline industry, which was one of the most disrupted industries. Recurring flight cancellations due to lockdown periods, staff reduction and other restrictions led various airline companies to bankruptcy or on the verge of being bankrupt. Third, financial performance and financial equilibrium were 
measured via certain indicators. Nevertheless, other research studies might investigate company rankings via the TOPSIS method by employing other relevant financial indicators recommended in the literature [40].

Author Contributions: Conceptualization, A.-D.C.; methodology, A.-D.C.; validation, A.-D.C.; formal analysis, A.-D.C.; resources, L.B., H.T.; data curation, A.-D.C.; writing—original draft preparation, A.-D.C.; writing-review and editing, L.B., H.T.; visualization, A.-D.C., L.B. and H.T. All authors have read and agreed to the published version of the manuscript.

Funding: This research was funded by the 2020 Development Fund of the Babes-Bolyai Universi-ty, Cluj-Napoca, Romania.

Institutional Review Board Statement: Not applicable.

Informed Consent Statement: Not applicable.

Data Availability Statement: The information regarding the ranking of airline companies was retrieved from www.fortune.com (accessed on 9 December 2020) and www.worldairlineawards.com (accessed on 11 December 2020). Financial information about companies was taken from the Thomson Reuters database.

Conflicts of Interest: The authors declare no conflict of interest.

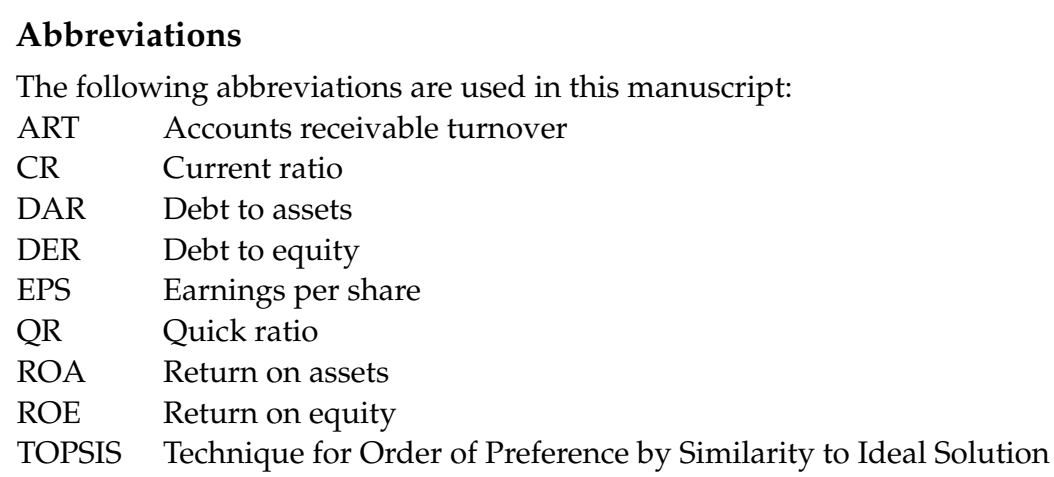

\section{Appendix A}

The sample includes the following companies: Qatar Airways, Singapore Airlines, ANA All Nippon Airways, Cathay Pacific Airways, EVA Air, Hainan Airlines, Qantas Airways, Lufthansa, Thai Airways, Japan Airlines, China Southern Airlines, Air New Zealand, Bangkok Airways, AirAsia, Air France, Virgin Australia, Turk Hava Yollari, Asiana Airlines, Finnair Plc, China Airlines, Southwest Airlines, and Delta Air Lines.

\section{References}

1. Chun, R. Corporate reputation: Meaning and measurement. Int. J. Manag. Rev. 2005, 7, 91-109. [CrossRef]

2. Fombrun, C.J.; Gardberg, N.A. Who's tops in corporate reputation? Corp. Reput. Rev. 2000, 3, 13-17. [CrossRef]

3. Hall, R. The strategic analysis of intangible resources. Strateg. Manag. J. 1992, 13, 135-144. [CrossRef]

4. Wang, Y.J. Applying FMCDM to evaluate financial performance of domestic airlines in Taiwan. Expert Syst. Appl. 2008, 34, 1837-1845. [CrossRef]

5. Batrancea, I.; Batrancea, L.; Nichita, A.; Gaban, L.; Masca, E.; Morar, I.-D.; Fatacean, G.; Moscviciov, A. An econometric approach on production, costs and profit in Romanian coal mining enterprises. Econ. Res.-Ekonomska Istraživanja 2019, 32, $1019-1036$. [CrossRef]

6. Batrancea, I.; Batrancea, L.; Rathnaswamy, M.M.; Tulai, H.; Fatacean, G.; Rus, M.-I. Greening the financial system in USA, Canada and Brazil: A panel data analysis. Mathematics 2020, 8, 2217. [CrossRef]

7. Kang, K.H.; Lee, S.; Huh, C. Impacts of positive and negative corporate social responsibility activities on company performance in the hospitality industry. Int. J. Hosp. Manag. 2010, 29, 72-82. [CrossRef]

8. Batrancea, I.; Moscviciov, A.; Sabau, C.; Batrancea, L.M. Banking crisis: Causes, characteristic and solutions. Proc. DIEM 2013, 1, 16-29.

9. Tarawneh, M.A. Comparison of financial performance in the banking sector: Some evidence from Omani commercial banks. Int. Res. J. Finance Econ. 2006, 3, 101-112. 
10. Neely, A.; Adams, C.; Kennerley, M. The Performance Prism: The Scorecard for Measuring and Managing Business Success; Prentice Hall: Hoboken, NJ, USA, 2002.

11. Hammond, S.A.; Slocum, J.W. The impact of prior firm financial performance on subsequent corporate reputation. J. Bus. Ethics 1996, 15, 159-165. [CrossRef]

12. Kenton, W. What Is Financial Performance? 2021. Available online: https://www.investopedia.com/terms/f/financialperformance. asp (accessed on 23 May 2021).

13. Verma, E. Financial Performance-Understanding Its Concepts and Importance. 2021. Available online: https://www.simplilearn. com/financial-performance-rar21-article (accessed on 14 May 2021).

14. Alniacik, E.; Alniacik, U.; Erdogmus, N. How do the dimensions of corporate reputation affect employment intentions? Corp. Reput. Rev. 2012, 15, 3-19. [CrossRef]

15. Davies, G.; Chun, R.; da Silva, R.V.; Roper, S.A. Corporate character scale to assess employee and customer views of organization reputation. Corp. Reput. Rev. 2004, 7, 125-146. [CrossRef]

16. Pavić, Z.; Novoselac, V. Notes on TOPSIS Method. Int. J. Res. Eng. Sci. 2013, 1, 5-12.

17. Chu, T.-C.; Lin, Y.-C. A fuzzy TOPSIS method for robot selection. Int. J. Adv. Manuf. Technol. 2003, 21, 284-290. [CrossRef]

18. García-Cascales, M.S.; Lamata, M.T. On rank reversal and TOPSIS method. Math. Comput. Model. 2012, 56, 123-132. [CrossRef]

19. Lee, J.; Roh, J.J. Revisiting corporate reputation and firm performance link. Benchmarking Int. J. 2012, 19, 649-664. [CrossRef]

20. Blajer-Golebiewska, A.; Kozlowski, A. Financial determinants of corporate reputation: A short-term approach. Manag. Econ. 2016, 17, 179-201. [CrossRef]

21. Rindova, V.P.; Williamson, I.O.; Petkova, A.P. Reputation as an intangible asset: Reflections on theory and methods in two empirical studies of business school reputations. J. Manag. 2010, 36, 610-619. [CrossRef]

22. Cravens, K.; Oliver, E.G.; Ramamoorti, S. The reputation index: Measuring and managing corporate reputation. Eur. Manag. J. 2003, 21, 201-212. [CrossRef]

23. Trotta, A.; Cavallaro, G. Measuring corporate reputation: A framework for Italian banks. Int. J. Econ. Finance Stud. 2012, 4, 21-30.

24. Juan, M.; Esther, O.P. Empirical analysis of the relationship between corporate reputation and financial performance: A survey of the literature. Corp. Reput. Rev. 2003, 6, 161-177. [CrossRef]

25. Caliskan, E.N.; Icke, B.T.; Ayturk, Y. Corporate reputation and financial performance: Evidence from Turkey. Res. J. Int. Stud. 2011, 18, 61-72.

26. Arshad, R.; Othman, S.; Othman, R. Islamic corporate social responsibility, corporate reputation and performance. Int. J. Soc. Behav. Educ. Econ. Bus. Ind. Eng. 2012, 6, 643-647. [CrossRef]

27. Caruana, A. Corporate reputation: Concept and measurement. Corporate reputation: Concept and measurement. J. Prod. Brand Manag. 1997, 6, 109-118. [CrossRef]

28. Flanagan, D.J.; O'Shaughnessy, K.C.; Palmer, T.B. Re-assessing the relationship between the fortune reputation data and financial performance: Overwhelming influence or just a part of the puzzle? Corp. Reput. Rev. 2011, 14, 3-14. [CrossRef]

29. Fryxell, G.E.; Wang, J. The fortune corporate "reputation" index: Reputation for what? J. Manag. 1994, 1, 1-14. [CrossRef]

30. Batrancea, L.; Nichita, A. Which is the best government? Colligating tax compliance and citizens' insights regarding authorities' actions. Transylv. Rev. Adm. Sci. 2015, 44E, 5-22.

31. Nichita, A.; Batrancea, L.; Pop, C.M.; Batrancea, I.; Morar, I.D.; Masca, E.; Roux-Cesar, A.M.; Forte, D.; Formigoni, H.; da Silva, A.A. We learn not for school but for life: Empirical evidence of the impact of tax literacy on tax compliance. East. Eur. Econ. 2019, 57, 397-429. [CrossRef]

32. Sanda, A.; Mikailu, A.S.; Garba, T. Corporate governance mechanisms and firm financial performance in Nigeria. In Africa Economic Research Consortium Research Paper; 2005; Available online: http:/ / oer.udusok.edu.ng/xmlui/handle/123456789/764 (accessed on 29 August 2021).

33. Berman, S.L.; Wicks, A.C.; Kotha, S.; Jones, T.M. Does stakeholder orientation matter? The relationship between stakeholder management models and firm financial performance. Acad. Manag. J. 1999, 42, 488-506.

34. Bulgurcu, B. Application of TOPSIS technique for financial performance evaluation of technology firms in Istanbul Stock Exchange Market. Procedia-Soc. Behav. Sci. 2012, 62, 1033-1040. [CrossRef]

35. Gerber, B. 12 Key Financial Performance Indicators You should Be Tracking. 2020. Available online: https://www. accountingdepartment.com/blog/12-key-performance-indicators-you-should-be-tracking (accessed on 15 May 2021).

36. Özçelik, F.; Gürsakal, S. Corporate governance and firm performance: Evidence from Borsa Istanbul (BIST). In Current Debates in Finance \& Econometrics; Gönüllü, O., Yıldız, H., Eds.; IJOPEC: London, UK, 2018; Volume 19, pp. 45-54.

37. Hwang, C.L.; Yoon, K. Methods for Multiple Attribute Decision Making-Methods and Applications: A State-of-the-Art Survey; Springer: Berlin/Heidelberg, Germany, 1981.

38. Feng, C.H.; Wang, R.T. Performance evaluation for airlines including the consideration of financial ratios. J. Air Transp. Manag. 2000, 6, 133-142. [CrossRef]

39. Roberts, P.W.; Dowling, G.R. Corporate reputation and sustained superior financial performance. Strateg. Manag. J. 2002, 23, 1077-1093. [CrossRef]

40. Batrancea, L. An econometric approach regarding the impact of fiscal pressure and equilibrium: Evidence from electricity, gas and oil companies listed on the New York Stock Exchange. Mathematics 2021, 9, 630. [CrossRef] 